\title{
Analisis dan Perancangan Sistem Informasi Pembuatan Daily Report Produksi Dies Berbasis Web
}

\author{
Dudi Awalludin ${ }^{1}$, Donny Apdian², Vina Kristiani ${ }^{3}$ \\ Jurnal Algoritma \\ STMIK Rosma \\ Jl. Kertabumi No.62, Karawang Barat, Kab. Karawang, Jawa Barat 41311 Indonesia \\ Email : stmik@rosma.ac.id \\ 11udi@rosma.ac.id \\ 2donny@dosen.rosma.ac.id \\ ${ }^{3}$ V.kristiani94@gmail.com
}

\begin{abstract}
Abstrak - Daily Report merupakan salah satu laporan harian yang sangat diperlukan oleh perusahaan manufaktur yang memproduksi produk Dies Casting (Cetakan). Belum maksimalnya pembuatan daily report pada produksi dies dalam suatu proyek menyebabkan sering terjadi kesalahan dalam pencatatan selama ini. Pencatatan ke dalam Microsoft Excel yang bersumber dari Form daily report yang pencatatannya dengan menggunakan tulis tangan sehingga sering terjadi kesalahan pengutipan disebabkan tulisan yang tidak terbaca atau kurang jelas, juga sering terjadi pencatatan yang berulang untuk data yang sama. Untuk mengurangi kesalahan atau permasalahan yang terjadi maka diperlukannya pengembangan sistem informasi pembuatan Daily Report produksi Dies yang sedang berjalan supaya bisa mengurangi kesalahan karena dalam memasukkan data daily report. Metodologi pengembangan sistem yang menggunakan SDLC dengan model Waterfall yang memiliki 6 pengembangan tahapan yang dipergunakan pada penelitian ini adalah System Engineering, Requirement Analysis serta Design. Sistem informasi pembuatan daily report produksi dies berbasis web yang dirancang dapat mengelola data berdasarkan daily report untuk mengurangi pencatatan manual perhitungan waktu produksi dies agar data yang disajikan sesuai dan dapat mengurangi kesalahan yang biasa terjadi ketika menggunakan sistem yang lama.
\end{abstract}

Kata kunci - Dies; Daily Report; Sistem Informasi; Web.

\section{PENDAHULUAN}

Perusahaan manufaktur PT XXX merupakan perusahan yang memproduksi Dies Casting (cetakan), jenis cetakan yang diproses adalah blank, forming, restrike, draw, trim dan pierce. Proses produksi pada suatu perusahan manufaktur merupakan hal yang utama, sehingga aktifitas ini harus direncanakan secara matang. Departemen Dies Shop sangat memperhatikan perencanaan proses produksi berjalan secara akurat dan matang, sangat memperhatikan perencanaan pelaporan harian yang dilakukan oleh operator produksi melalui dokumen form daily report yang ditulis tangan yang telah diperiksa oleh leader disetiap section (divisi/bagian), kemudian ditandatangani atau disetujui oleh section head (kepala bagian). Kemudian diberikan kepada staf produksi untuk dimasukan kedalam komputer dengan menggunakan aplikasi Ms. Excel. Ass. section head CAD/CAM (Computer Aided Design/Computer Aided Manufacturing) melakukan pemeriksaan catatan daily report setiap bulannya guna diolah kembali sesuai dengan class, diantaranya normal, abnormal, dan modifikasi serta content (proses pengerjaan dari masing-masing section) untuk mengetahui berapa lama proses produksi Dies, menghitung kapasitas mesin, rencana pengambilan proyek baru serta jadwal pengiriman. Setiap proyek bisa memakan waktu proses pengerjaan 4 bulan hingga 6 bulan dan setelah project selesai para pimpinan akan mengevaluasi waktu proses pengerjaan serta perencanaan pengambilan proyek baru. Namun, pencatatan data 
yang telah dikelola dan dikelompokkan oleh assistant section head CAD/CAM yang dilakukan setiap bulan dalam satu file ini memerlukan waktu yang cukup lama jika para pimpinan ingin melihat data waktu proses pengerjaan dies dalam satu project karena harus membuka file tiap bulannya dan sering terjadi kesalahan dalam memasukkan data, sehingga dapat menimbulkan kendala dalam kinerja perusahaan.

Berdasarkan permasalahan tersebut, maka penelitian ini bertujuan untuk merancang sistem informasi perhitungan kapasitas waktu produksi yang dapat memberikan informasi yang akurat guna mengetahui berapa normal time, abnormal dan modification yang diperlukan dalam proses dies dari setiap section.

\section{TINJAUAN PUSTAKA}

Analisis sistem dapat diartikan suatu proses untuk memahami sistem yang ada dengan menganalisa jabatan dan uraian tugas (business user). Proses bisnis (business proces), ketentuan atau aturan (business rule), masalah dan solusinya (business problem and solution), dan rencana-rencana perusahaan (business plan) [1]. Perancangan adalah proses pengembangan spesifikasi baru berdasarkan rekomendasi hasil analisis sistem [2]. Perancangan merupakan kegiatan untuk membentuk membuat sketsa struktur kegiatan atau pekerjaan dari suatu analisis ke dalam suatu perencanaan untuk dapat diterapkan dalam suatu bentuk nyata [3]. Perancangan sistem merupakan sebuah penentuan pada proses dan data yang diperlukan oleh sebuah sistem baru, hal ini dikarenakan tujuan dari perancangan sistem untuk memenuhi kebutuhan dari pemakai sistem kemudian memberikan sebuah gambaran jelas serta rancang bangun yang lengkap [4]. Sistem Informasi (Information System) merupakan kombinasi teratur dari orang-orang, perangkat keras, perangkat lunak, jaringan komunikasi, dan sumber daya data yang mengumpulkan, mengubah, menyebarkan informasi dalam sebuah organisasi [1].

Produksi merupakan kegiatan dalam mentransformasikan input menjadi sebuah output, yang mencakup segala aktifitas/kegiatan yang menghasilkan barang ataupun jasa, bahkan kegiatan lainnya yang mendukung/usaha didalam menghasilkan produksi [5]. Pengecoran (casting) adalah suatu proses penuangan materi cair seperti logam atau plastik yang dimasukkan ke dalam cetakan, kemudian dibiarkan membeku di dalam cetakan tersebut, dan kemudian dikeluarkan atau dipecah-pecah untuk dijadikan komponen mesin [6]. Model Waterfall merupakan salah satu model dalam pengembangan sistem yang memiliki enam (6) tahapan yaitu System Enginereeng, Requirement Analysis, Design, Coding, Testing, dan Maintenance[3]. Tahapan yang akan dipergunakan pada penelitian ini hanya tahapan System Enginereeng, Requirement Analysis, dan Design. Website merupakan kumpulan halaman yang menampilkan informasi berupa teks, data, gambar, data animasi, suara, dan video yang dibuat secara berkaitan dalam hyperlink [7].

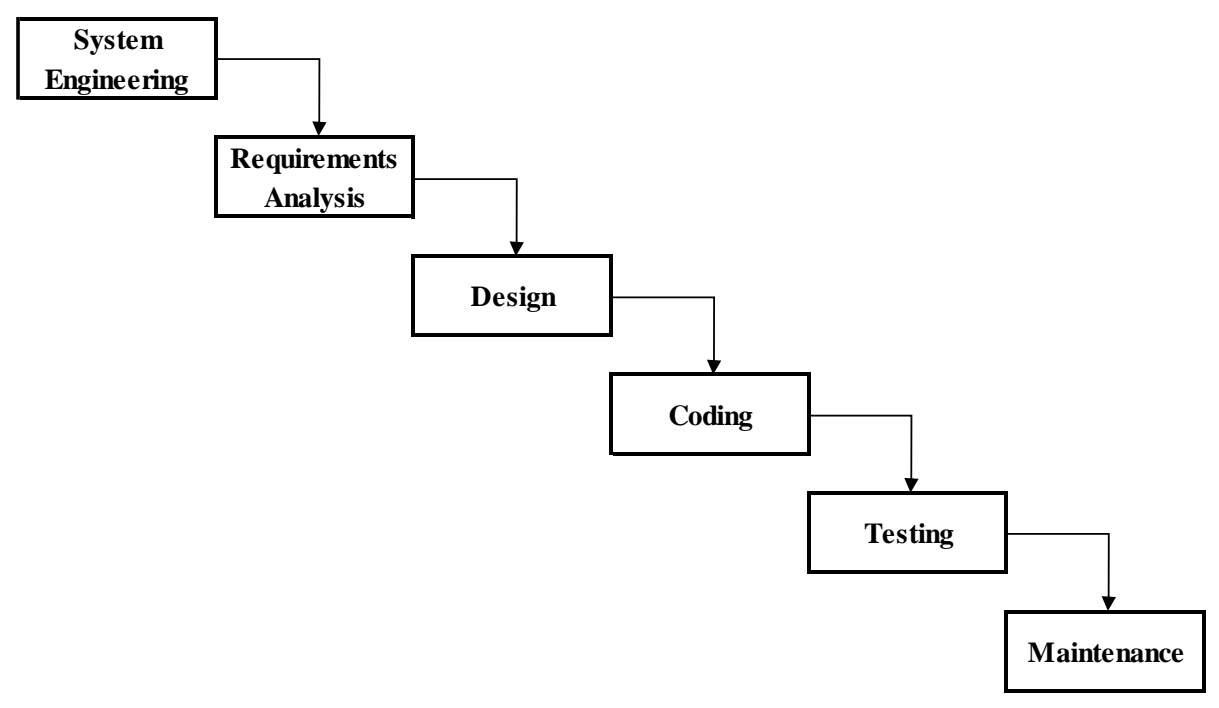

Gambar 1: Metode Pengembangan Waterfall 
Peninjauan pustaka bukan hanya berdasarkan teori dasar tetapi juga berdasarkan hasil penelitian yang telah dilakukan sebelumnya diantarany :

1. Setelah dilakukan perhitungan tentang perencanaan kapasitas produksi menggunakan metode RCCP yang diperlukan untuk memenuhi permintaan konsumen, apabila disintesakan bahwa perencanaan kapasitas waktu produksi setiap stasiun kerja mengalami penurunan sehingga waktu produksi yang tersedia menjadi optimal [8].

2. Integer Linear Programming (ILP) perhitungan yang digunakan untuk mengoptimalkan kapasitas produksi pada stasiun kerja dari sebuah mesin pompa air dalam mempersiapkan penyusunan jadwal produksi oleh pimpinan produksi. Berdasarkan perhitungan ILP dapat diketahui bahwa jumlah produksi yang optimal dengan minimum perintah produksi yang tersisa berdasarkan SOP dan total keuntungan yang diperoleh dari peningkatan kapasitas dengan penambahan jam kerja (jam lembur).[9].

3. Dengan adanya sistem daily activity report, proses komunikasi terkait pendelegasian tugas menjadi lebih teratur dan mudah untuk ditelusuri kembali. Sistem ini dapat dikembangkan dengan mengintegrasikannya dengan sistem informasi personalia, dimana sistem ini dapat membantu dalam memperhitungkan Key Performance Index (KPI) karyawan dalam faktor pelaksanaan tugas [10].

4. Dalam penelitian ini, telah dibangun sebuah sistem informasi yang dapat digunakan untuk membuat penjadwalan berdasarkan metode FCFS (First Come First Served), dan dapat memperbarui jadwal berdasarkan waktu aktual yang diperoleh dari bagian produksi. [11].

5. Digunakan pendekatan ESCM di dalam menganalisis sebuah model, perancangan serta implementasi perangkat lunak untuk prototype sistem perencanaan produksi, Semantic Web menggunakan framework Codeigniter, dan Responsive Design pada PT. Argo Pantes Tbk dapat dengan mudah dibangun dan berfungsi untuk menyediakan data dan informasi yang dibutuhkan oleh pengguna khususnya bagi para eksekutif sebagai acuan dalam perencanaan produksi dan pengambilan keputusan dengan menggunakan metode pengembangan Evolutionary Prototype [12].

\section{III.METODOLOGI PENELITIAN}

Tahapan yang terdapat pada gambar 1 tidak akan dibahas semua tetapi hanya tiga (3) tahapan yang akan dilakukan dalam penelitian:

1. Rekayasa sistem, merupakan tahapan awal model waterfall yang menjelaskan kegiatan pada tahapan ini adalah pengumpulan data. Metode pengumpulan data yang akan dilakukan adalah

a. Observasi, merupakan suatu metode pengumpulan data dengan cara mengamati seluruh kegiatan yang berhubungan dalam perhitungan kapasitas waktu produksi Dies yang meliputi prosedur pengisian form daily report, prosedur pemeriksaan form daily report yang telah diisi oleh operator produksi, prosedur pencatatan laporan daily report, dan prosedur pengelolaan data daily report.

b. Wawancara, kegiatan ini merupakan aktifitas dalam pengumpulan data yang langsung melakukan Tanya jawab dengan nara sumber. Nara sumber dari kegiatan ini adalah dari Departement Dies Shop diantaranya Staf produksi dan asisten Section Head CAD/CAM. Mengumpulkan data berupa dokumen kerja, alur kerja dan dokumen pendukung lainnya.

c. Studi Pustaka, metode pengumpulan data dengan cara mencari data melalui sumber-sumber yang tercatat, dan tercetak baik dalam bentuk buku pedoman, Standar operasional prosedur (SOP) dan sumber tercatatn lainnya

2. Requirements Analysis, tahapan merupakan tahapan menganalisis sistem yang tengah berjalan dengan menggunakan tools Flow of Document.

3. Design, pada tahapan ini digunakan tools perancangan sistem yaitu DFD (Data Flow Diagram), perancangan ERD (Entity Relationship Diagram), serta perancangan input dan output. 


\section{IV.HASIL DAN PEMBAHASAN}

Tahap pertama yaitu System Engineering yang akan dibahas adalah tahapan pengumpulan data yang menggunakan metode observasi, wawancara dan studi pustaka. Dari kegiatan ini menghasilkan beberapa data yang akan dipergunakan untuk tahapan berikutnya.

PT XXX memiliki bagian Administrasi dan 3 departemen yaitu Casting, Dies Shop, dan Parts total sumber daya manusia (SDM) seluruhnya 643 orang tenaga kerja lokas dan 15 orang tenaga kerja asing. Departement Dies shop memiliki SDM 61 orang tenaga kerja lokal dan tiga (3) orang tenaga kerja asing, depertamen ini memiliki jenjang pendidikan sarjana sampai Sekolah Menengah Atas (SMA)/Sekolah Menengah Kejuruan (SMK).

Dibawah ini ada beberapa data yang terkait dengan penelitian diantaranya yaitu fasilitas, jenis mesin produksi Dies, serta Dies itu sendiri seperti terlihat pada tabel dibawah ini.

Tabel 1: Fasilitas Dies Shop Deprt

\begin{tabular}{clc}
\hline No. & \multicolumn{1}{c}{ Nama Fasilitas } & Jumlah (Unit) \\
\hline 1 & Crane (Daya Angkut 15 ton) & 2 \\
\hline 2 & Crane (Daya Angkut 10 ton) & 1 \\
\hline 3 & Crane (Daya Angkut 5 ton) & 2 \\
\hline 4 & Crane (Daya Angkut 3 ton) & 3 \\
\hline 5 & Crane (Daya Angkut 2,8 ton) & 1 \\
\hline
\end{tabular}

Tabel 2: Mesin Produksi

\begin{tabular}{clc}
\hline No. & Jenis Mesin & Jumlah (Unit) \\
\hline 1 & CNC & 4 \\
\hline 2 & Bubut & 2 \\
\hline 3 & Milling & 2 \\
\hline 4 & Drill & 1 \\
\hline 5 & Press & 1 \\
\hline 6 & Shearing & 1 \\
\hline 7 & Grinding Surface & 2 \\
\hline 8 & Band Saw & 1 \\
\hline
\end{tabular}

Tabel 3: Jenis Dies

\begin{tabular}{cll}
\hline No. & \multicolumn{1}{c}{ Jenis Dies } & \multicolumn{1}{c}{ Keterangan } \\
\hline 1 & Blank & Potongan pembentukan awal \\
\hline 2 & Forming & Pembentukan dengan tekukan-tekukan pada Part \\
\hline 3 & Restrike & Menyempurnakan pembentukan \\
\hline 4 & Draw & Menekan Blank \\
\hline 5 & Trim & Pemotongan sisa material yang tidak berguna \\
\hline 6 & Pierce & Pembentukan lubang pada Part \\
\hline
\end{tabular}

Dokumen yang terlibat dalam sistem informasi pembuatan Daily Report produksi dies tiga (3) buah dokumen, yaitu:

1. Form Daily Report : merupakan formulir blanko berfungsi sebagai dokumen yang mencatat segala kegiatan operator dalam proses produksi dies maupun diluar produksi yang berlangsung setiap hari. Dokumen ini sumber data berasal dari staff produksi.

2. Die Shop Daily Report : yang selanjutnya disebut dengan Daily Report merupakan dokumen Form Daily Report yang telah di isi lengkap oleh Operator. Dokumen ini memiliki fungsi sebagai dokumen kegiatan setiap produksi yang berlangsung setiap hari. Sumber data dari dokumen form daily report lengkap yang diperoleh dari section head. 
3. Laporan Daily Report per Project : berfungsi sebagai hasil laporan Daily Report yang telah diolah datanya setiap bulan oleh assistant section head CAD/CAM menjadi data Daily Report per Project.

Tahapan Kedua yaitu Requirements Analysis

Sistem Pembuatan Daily Report yang berjalan saat ini melibatkan enam (6) entitas yaitu Operator, Leader, Staf Produksi, Assisten Section Head CAD/CAM, Section Head, serta Manajer. Berikut alur yang terjadi pada sistem pembuatan Daily Report seperti dibawah ini:

1. Staf Produksi

a. Menyiapkan Form Daily Report untuk operator.

b. Memasukkan data form daily report yang telah diperiksa dan ditandatangan oleh section head.

2. Operator

a. Menerima kemudian Mengisi Form Daily Report yang diberikan oleh Staf Produksi.

b. Menyerahkan Form Daily Report yang sudah di isi dengan lengkap kemudian disebut Daily Report kepada Leader untuk diperiksa dan ditandatangani.

3. Leader

a. Memeriksa dan menandatangani Daily Report yang diterima dari Operator.

b. Setelah diperiksa, jika Daily Report tidak sesuai maka Daily Report tersebut akan dikembalikan kepada Operator agar dilengkapi, tetapi jika Daily Report lengkap, maka kemudian akan diserahkan kepada Section Head untuk ditandatangani atau disetujui.

4. Section Head

a. Menerima dan Menandatangani Daily Report dan sudah diperiksa oleh Leader.

b. Setelah Daily Report sudah ditandatangani atau disetujui maka akan diserahkan kembali kepada Staf Produksi.

5. Assistant Section Head CAD/CAM

a. Menerima Daily Report dari Staf Produksi, kemudian data tersebut diolah/dibagi menjadi data Laporan Daily Report Per Project.

b. Membuat Laporan Daily Report Per Project untuk diberikan kepada Manajer.

6. Manajer

Menerima Laporan Daily Report Per Project dari Assistant Section Head CAD/CAM. 


\section{Flow Document Sistem Berjalan}

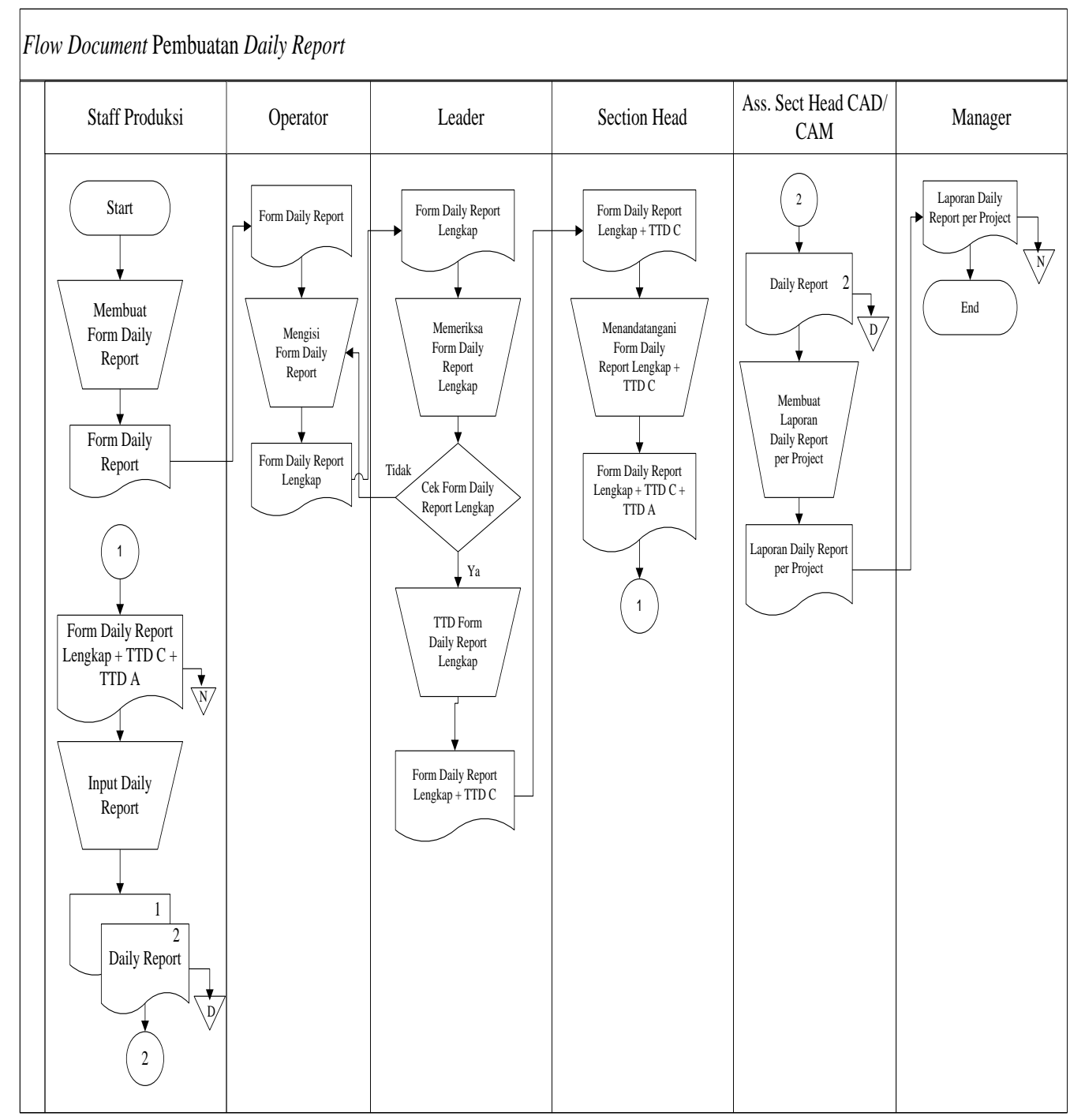

Gambar 2: Flow of Document Pembuatan Daily Report

Keterangan:

$\begin{array}{ll}\text { TTD C } & \text { : Tandatangan Confirmer } \\ \text { TTD A } & \text { : Tandatangan Approver } \\ \text { Ass. Sect. Head } & \text { : Assistant Section Head }\end{array}$

Analisis SWOT yang didapat dari menganalisa prosedur yang berjalan dan sistem yang akan diusulkan di PT XXX memiliki beberapa faktor, yaitu faktor internal dan faktor eksternal. Berikut adalah hasil analisis SWOT:

1. Faktor Internal

a. Kekuatan (Strength)

1) Memiliki kapasitas produksi yang cukup besar +/- 10 unit dies setiap bulan.

2) Satu-satunya perusahaan manufaktur dies terbesar dan terlengkap di daerah karawang.

3) Pemasok utama dies di daerah karawang.

4) Memiliki sertifikat ISO 9001:2008 dengan jaminan mutu/kualitas dies yang baik sehingga mutu/kualitas yang dihasilkan tidak mengecewakan customer.

5) Memilki fasilitas dan infrastruktur yang baik di departemen die shop.

6) Memiliki standar keamanan kerja yang tinggi untuk para karyawan.

7) Sistem yang akan diusulkan dapat mempercepat pembuatan Daily Report produksi dies. 
b. Kelemahan (Weakness)

1) Usia operator yang sudah kurang produktif $\geq 45$ tahun berjumlah 4 orang.

2) Kurangnya kriteria standar pendidikan karyawan.

3) Kurangnya jumlah operator produksi yang dibutuhkan sekitar 8 orang, total karyawan seharusnya ada 69 orang.

\section{Faktor Eksternal}

a. Peluang (Opportunity)

1) Kesempatan bisa bersaing cukup besar dengan perusahaan manufaktur dies yang ada di Indonesia.

2) Semakin banyaknya pemesanan dengan adanya Quality Control yang ketat sehingga menghasilkan kualitas dies yang baik.

3) Peluang untuk mengoptimalkan kapasitas produksi cukup besar.

4) Peluang untuk menambah pembuatan dies mobil truck, seperti mobil truck HINO.

b. Ancaman (Threats)

Semakin banyaknya perusahaan manufaktur khususnya dies.

Berdasarkan analisis SWOT (internal/eksternal) diketahui strength, weaknesess, opportunity dan threat, sehingga ketika strategi dirumuskan terdapat faktor penghambat dan akan dirumuskan pula faktor pendukung dari setiap strategi yang akan dilakukan oleh PT XXX khususnya di departemen Dies Shop.

\section{Flow System Usulan}

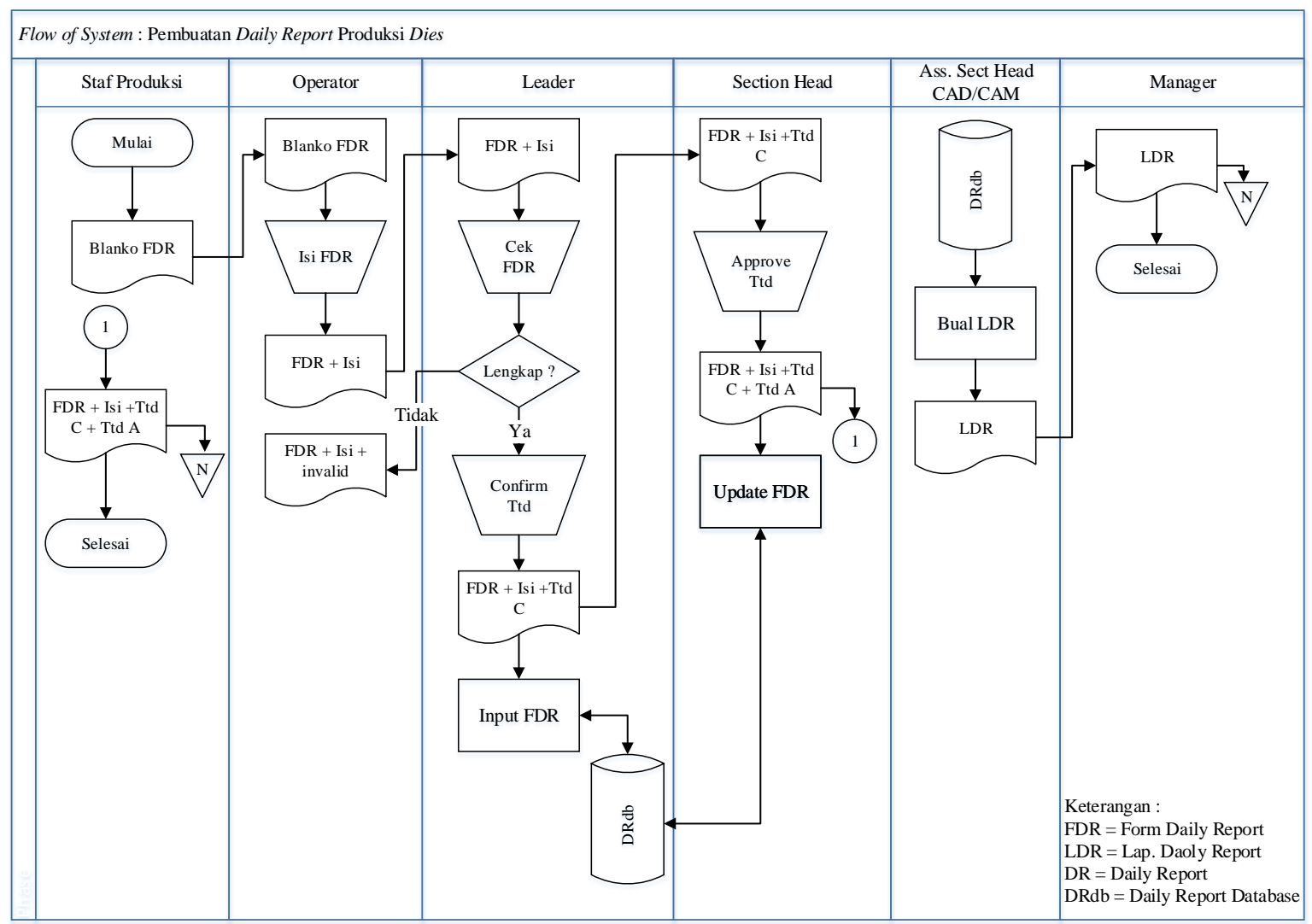

Gambar 3: Flow of System Usulan Pembuatan Daily Report 


\section{Diagram Konteks}

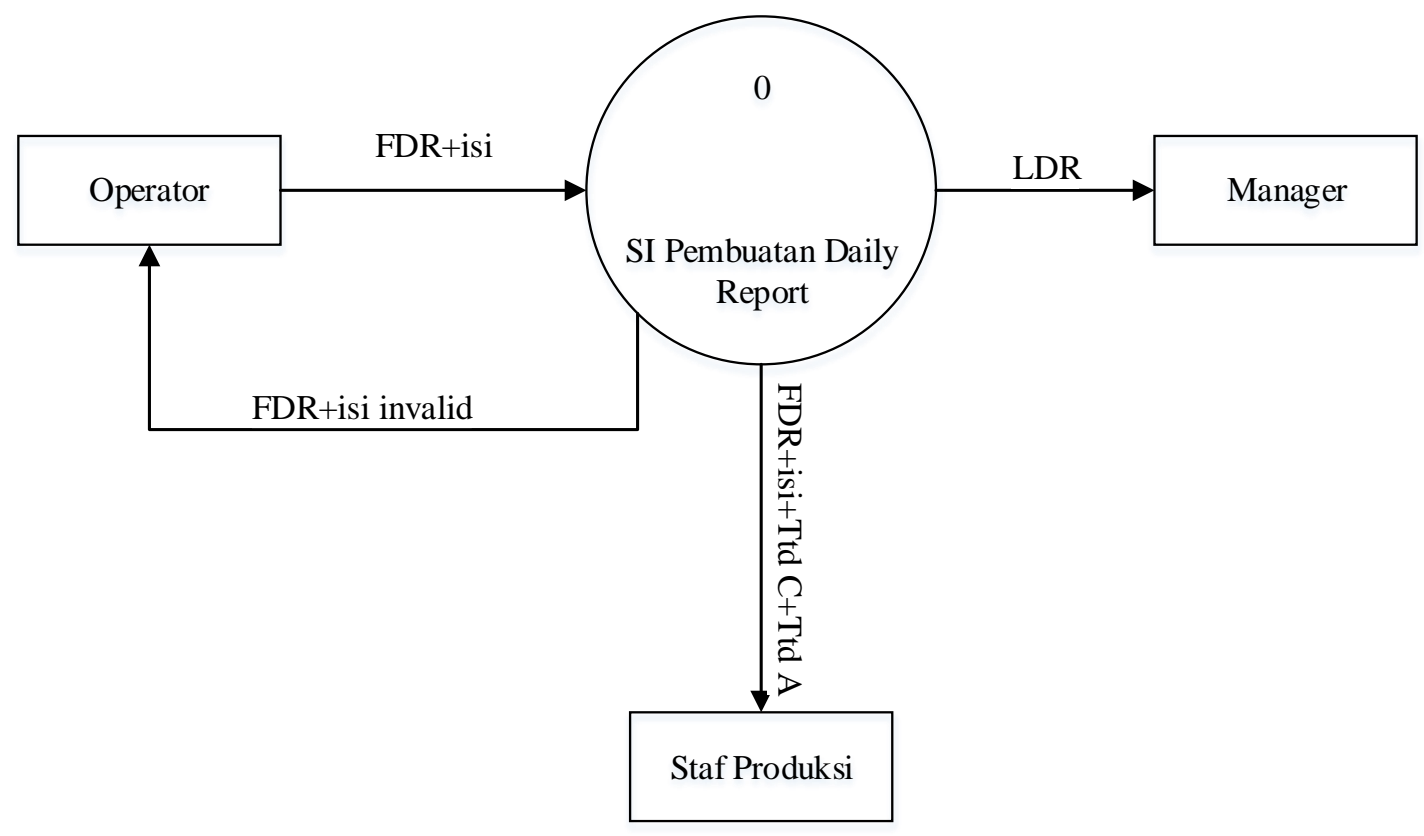

Gambar 3: Diagram Konteks Pembuatan Daily Report

\section{Diagram Overview}

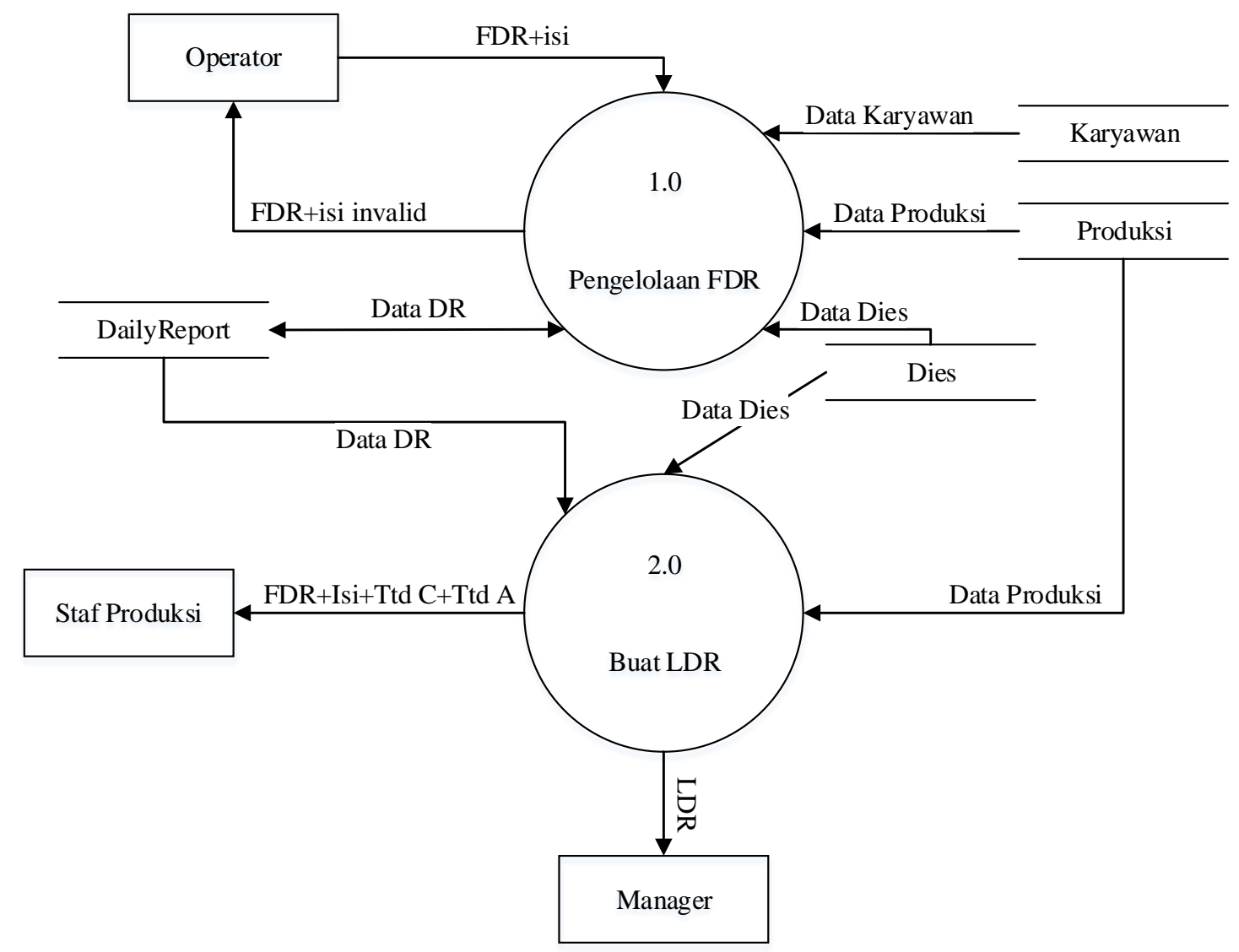

Gambar 4: DFD Level 1 Pembuatan Daily Report 


\section{Entity Relationship Diagram (ERD)}

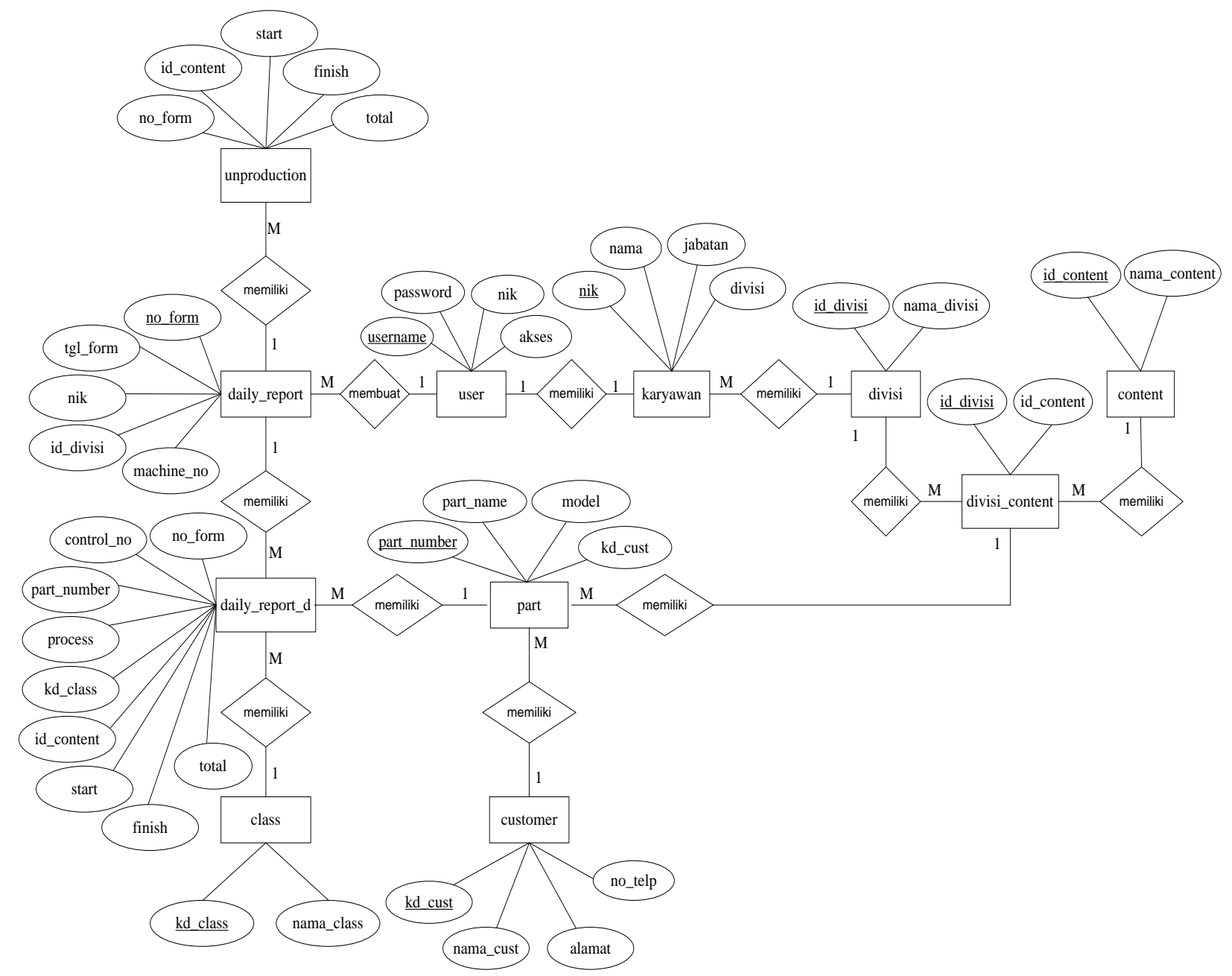

Gambar 5: ERD

\section{KESIMPULAN}

Berdasarkan pembahasan pada halaman sebelumnya, yang meliputi data-data pembuatan laporan penelitian dengan tema "Analisis dan Perancangan Sistem Informasi Pembuatan Daily Report Produksi Dies Berbasis Web", maka dapat diambil sintesa yaitu:

1. Dapat menyajikan data dengan cepat dan akurat.

2. Mempermudah karyawan dalam menghitung kapasitas waktu produksi dies.

3. Memiliki pengelolaan data yang baik.

4. Mempermudah dalam pencarian data waktu produksi dies dalam satu project.

\section{DAFTAR PUSTAKA}

[1] Yaqub, Pengantar Sistem Informasi. Yugyakarta: Graha Ilmu, 2012.

[2] M. Subhan, Analisa Perancangan Sistem. Jakarta: Lentera Ilmu Cendikia, 2012.

[3] Jogiyanto, Analisa dan Desain Sistem Informasi, 3rd ed. Yogyakarta, 2010.

[4] S. Mulyani, Metode Analisis dan Perancangan Sistem. 2017. 
[5] T. K. Pracoyo and A. Pracoyo, Aspek Dasar Ekonomi Mikro. Yogyakarta: Grasindo, 2006.

[6] Widarto, B. S. Wijanarka, Sutopo, and Paryanto, "Teknik Permesinan," Direktorat Pembin. Sekol. Menengah Kejuru., 2008.

[7] G. R. I. Pontoh and Arie S.M. Lumenta, "Arsip Digital Dokumen Kontrak Berbasis Web Pada Pt. Abdi Pratama Perkasa," E-Journal Tek. Elektro Dan Komput., vol. 5, no. 4, p. 25, 2016, doi: https://doi.org/10.35793/jtek.5.4.2016.13384.

[8] B. Santoso, "Perencanaan Kapasitas Waktu Produksi dengan Menggunakan Metode Rough Cut Capacity Planning (RCCP) Pada Produk 'Bale Cover' (Studi Kasus di PT.Wiharta Karya Agung Gresik)," Pros. Semin. Nas. Apl. Sains Teknol. Periode III, no. November, pp. 10-15, 2012.

[9] E. M. A. Christanty, N. W. Setyanto, and I. Hamdala, "Optimasi Kapasitas Produksi Dalam Penyusunan Jadwal Induk Produksi Menggunakan Integer Linear Programming ( ILP ) (Studi Kasus : CV . PABRIK MESIN GUNTUR MALANG)," Rekayasa dan Manaj. Sist. Ind., vol. 2, no. 6, pp. 1147-1157, 2014.

[10] L. Liliana and D. Pranoto, "Prosiding Seminar Nasional Teknologi Informasi dan Multimedia (SNASTIA) 2015," Pros. SNASTIA, no. 24 Okt 2015, pp. 74-79, 2015.

[11] Nafiurridha, Rispianda, and C. Nugraha, "Rancangan Sistem Informasi Penjadwalan Produksi pada Sistem Shop Floor Control *," Reka Integr., vol. 01, no. 04, pp. 35-46, 2014.

[12] T. Ika Jaya Kusumawati and Wulandari, "Prototipe Sistem Informasi Supply Gas Pertamina Dengan Pendekatan SCM Pada Koperasi,” J. Sist. Inf. Indones., vol. 2, no. 1, pp. 1-24, 2017. 